\title{
PASSIVE AND ACTIVE BIOMONITORING OF ATMOSPHERIC AEROSOL WITH THE USE OF MOSSES
}

\begin{abstract}
The aim of the carried out research was passive and active biomonitoring of woodlands in the Opole province. Pleurozium schreberi mosses were used during the research, in which the following heavy metals concentrations were determined: $\mathrm{Mn}, \mathrm{Fe}, \mathrm{Ni}, \mathrm{Cu}, \mathrm{Zn}, \mathrm{Cd}$ and $\mathrm{Pb}$. Concentrations were determined with absorption atomic spectrometry (AAS). On the basis of the carried out research, concentrations of heavy metals in moss samples used in the passive and active biomonitoring methods were compared. The obtained results indicate that Pleurozium schreberi mosses can be successfully used in both passive and active biomonitoring, however, these methods should not be used interchangeably in a defined study area. On the basis of carried out research it was determined that the applied biomonitoring methods can be supplementary.
\end{abstract}

Keywords: passive biomonitoring, active biomonitoring, mosses, heavy metals, atomic absorption spectrometry

\section{Introduction}

Biomonitoring is one of the biological methods for environment pollution level assessment. It allows to assess the quantity and influence of pollution on ecosystems. The method is based on suing the organisms with the ability to accumulate pollution present in the environment. Such organisms include bioindicators. The offer the possibility to obtain information on the quantitative and qualitative status of air pollution [1]. The analytes, which can be identified thanks to the use of biomonitors are, among others: heavy metals and polycyclic aromatic hydrocarbons [2,3]. Due to the type of the carried out research, we can distinguish active biomonitoring, involving exposition of an organism in a defined area and passive biomonitoring, which bases on the samples collected from their natural habitat [4-6].

According to literature, mosses, lichens and algae are some of the most frequently used bioindicators in environment pollution level assessment [7, 8]. Thanks to their specific structure, mosses absorb all substances with water through their whole surface. Easy availability and identifiability as well as sampling are additional advantages in the conducted research $[1,9]$.

Determining the content of heavy metals in environment is of key importance. They are particularly dangerous due to their negative influence on living organisms. Their emission to the environment causes pollution of water, fish fodder and vegetables [10, 12].

\footnotetext{
${ }^{1}$ Institute of Environmental Engineering and Biotechnology, University of Opole, ul. kard. B. Kominka 6a, 45-032 Opole, Poland, phone +48 774016042 , fax +48 774016051

${ }^{2}$ Institute of Biology, University of Opole, ul. Oleska 22, 45-052 Opole, Poland

*Corresponding authors: pawel.swislowski@uni.opole.pl; rajfur@uni.opole.pl,mrajfur@o2.pl
} 
Mosses as a bioindicator form determining heavy metals and other pollutants present in the environment are used not only in Poland [13-16], but also in other regions of the world among others in Albania [17, 18], Kosovo [19], Georgia [20], Spain [21], Canada [22], Croatia [23], Italy [24], Serbia [25] and Turkey [26]. That fact confirms that it is an organism, which can be effectively used in biomonitoring of environment pollution, regardless of the studied region and climate conditions.

Mosses Pleurozium schreberi are used both in pollution level assessment in natural environment, e.g. woodlands [27-29], industrial and urban areas [6, 13, 30, 31].

The objective of the presented research was to identify correlations between heavy metals concentrations determined in mosses, which were used in passive and active biomonitoring in the selected woodland areas. The study was carried out in the woodland areas of Opole province. Pleurozium schreberi mosses were used; the following heavy metals were determined using the atomic absorption spectrometry method: $\mathrm{Mn}, \mathrm{Fe}, \mathrm{Ni}, \mathrm{Cu}$, $\mathrm{Zn}, \mathrm{Cd}$ and $\mathrm{Pb}$.

\section{The research methodology}

Pleurozium schreberi mosses were used in the study carried out during the period July-September 2020. In passive biomonitoring mosses were collected in the woods of Turawa commune in Opole province (south-western Poland). Moss samples were collected from the locations with $1 \mathrm{~m} \times 1 \mathrm{~m}$ areas. The collected moss samples were taken to a laboratory and dried at room temperature, until dry mass was obtained. Green parts of gametophytes were separated from mosses and mineralised [32-34].

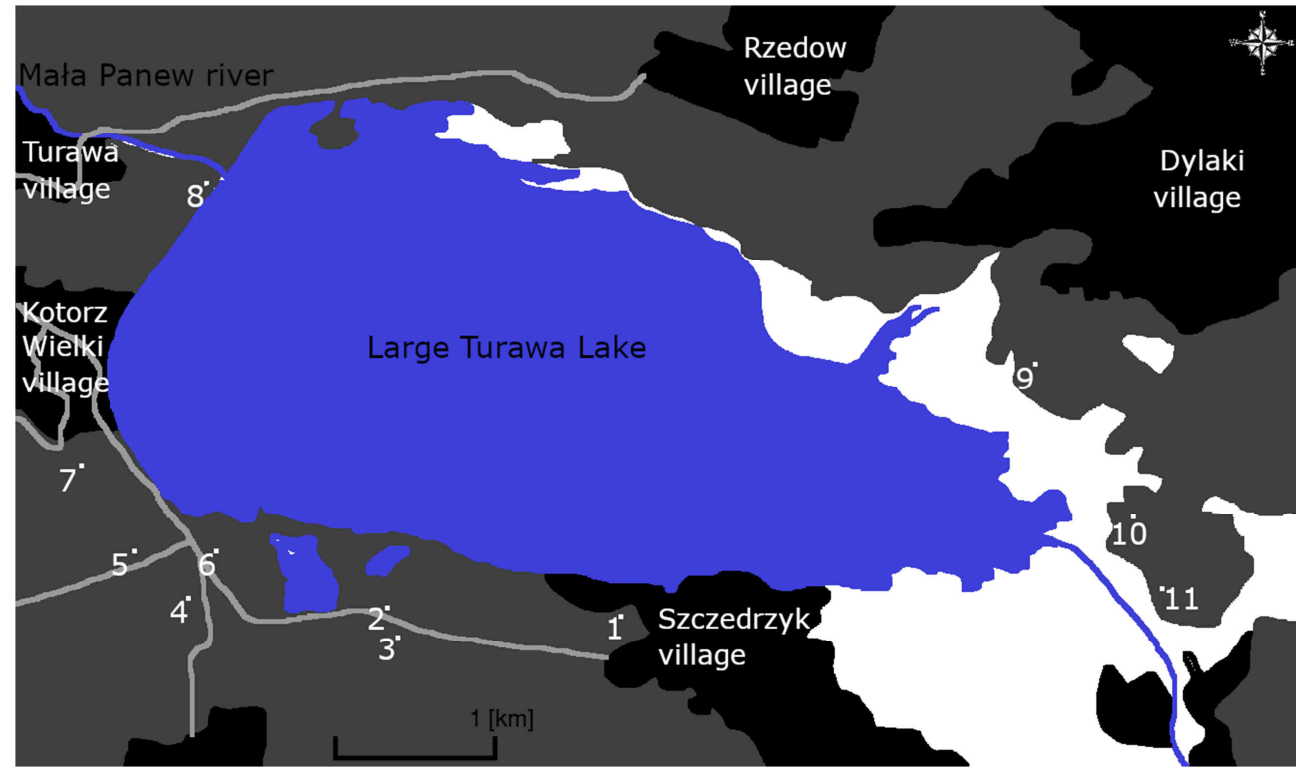

Fig. 1. Locations of biomonitoring studies (blue fields - reservoir, river; black fields - urban area; grey fields - woodlands; grey lines - roads) 
Active biomonitoring was carried out by exposing mosses for 3 months (moss sample mass $3.00 \mathrm{~g}$ ), collected from ecologically clean wood areas of Swietokrzyskie province, in 11 measuring location where mosses were collected within passive biomonitoring. Mosses were prepared prior to exposition, according to methodology [35]. The location of moss sample collecting - passive biomonitoring and sample exposition - active biomonitoring, are presented in the map in Figure 1.

Table 1 contains characteristics of the measurement locations and their GPS coordinates.

Table 1

GPS coordinates of measurement locations

\begin{tabular}{|c|c|c|}
\hline $\begin{array}{l}\text { Measurement } \\
\text { location no. }\end{array}$ & GPS coordinates & Measurement location description \\
\hline 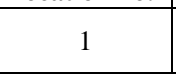 & $50^{\circ} 42^{\prime} 25.5^{\prime \prime} \mathrm{N} 18^{\circ} 08^{\prime} 04.4^{\prime \prime} \mathrm{E}$ & $\begin{array}{l}\text { Location on the woodland border, in the vicinity of Szczedrzyk } \\
\text { village }\end{array}$ \\
\hline 2 & $50^{\circ} 42^{\prime} 27.5^{\prime \prime} \mathrm{N} 18^{\circ} 06^{\prime} 40.5^{\prime \prime} \mathrm{E}$ & Location in the woods, approximately $150 \mathrm{~m}$ from the nearest road \\
\hline 3 & $50^{\circ} 42^{\prime} 20.9^{\prime \prime} \mathrm{N} 18^{\circ} 06^{\prime} 45.1^{\prime \prime} \mathrm{E}$ & Location in the woods, approximately $250 \mathrm{~m}$ from the nearest road \\
\hline 4 & $50^{\circ} 42^{\prime} 29.3^{\prime \prime} \mathrm{N} 18^{\circ} 05^{\prime} 29.0^{\prime \prime} \mathrm{E}$ & Location in the woods, approximately $300 \mathrm{~m}$ from the road \\
\hline 5 & $50^{\circ} 42^{\prime} 40.0^{\prime \prime} \mathrm{N} 18^{\circ} 05^{\prime} 07.2^{\prime \prime} \mathrm{E}$ & Location in the woods, approximately $400 \mathrm{~m}$ from the road \\
\hline 6 & $50^{\circ} 42^{\prime} 40.1^{\prime \prime} \mathrm{N} 18^{\circ} 05^{\prime} 37.4 " \mathrm{E}$ & $\begin{array}{l}\text { Location in the woods, close to bicycle paths between the large and } \\
\text { medium Turawa lakes }\end{array}$ \\
\hline 7 & $50^{\circ} 42^{\prime} 59.5^{\prime \prime} \mathrm{N} 18^{\circ} 04^{\prime} 44.3^{\prime \prime} \mathrm{E}$ & $\begin{array}{c}\text { Location in the woods, approximately } 1 \mathrm{~km} \text { from Kotorz Wielki } \\
\text { village and } 500 \mathrm{~m} \text { away from the road }\end{array}$ \\
\hline 8 & $50^{\circ} 44^{\prime} 10.0^{\prime \prime} \mathrm{N} 18^{\circ} 05^{\prime} 20.8^{\prime \prime} \mathrm{E}$ & $\begin{array}{c}\text { Location in the woods, approximately } 15 \mathrm{~km} \text { from water power } \\
\text { plant and } 500 \mathrm{~m} \text { away from the road }\end{array}$ \\
\hline 9 & $50^{\circ} 43^{\prime} 24.8^{\prime \prime} \mathrm{N} 18^{\circ} 10^{\prime} 39.7^{\prime \prime E}$ & $\begin{array}{c}\text { Location in the woods, approximately } 2 \mathrm{~km} \text { away from any } \\
\text { settlement and road }\end{array}$ \\
\hline 10 & $50^{\circ} 42^{\prime} 48.7^{\prime \prime} \mathrm{N} 18^{\circ} 11^{\prime} 11.3 " \mathrm{E}$ & Location in the woods, near a bicycle path \\
\hline 11 & $50^{\circ} 42^{\prime} 32.1 " \mathrm{~N} 18^{\circ} 11^{\prime} 19.7 " \mathrm{E}$ & $\begin{array}{l}\text { Location near bicycle paths, on the eastern shore of the large } \\
\text { Turawa lake }\end{array}$ \\
\hline
\end{tabular}

\section{Equipment and reagents}

The representative (averaged) moss samples with the mass of $1.000 \pm 0.001 \mathrm{~g}$ d.m. (d.m. - dry mass) were mineralised in the mixture of nitric acid(V) and hydrochloric acid $\left(\mathrm{HNO}_{3} 65 \%: \mathrm{H}_{2} \mathrm{O}_{2} 30 \%=3: 1\right)$ using a Speedwave Four Berghof, DE microwave oven. The mineralization process temperature was $180^{\circ} \mathrm{C}$. MERCK company reagents were used to prepare solutions. Heavy metals ( $\mathrm{Mn}, \mathrm{Fe}, \mathrm{Ni}, \mathrm{Cu}, \mathrm{Zn}, \mathrm{Cd}$ and $\mathrm{Pb}$ ) in the mineralised samples were determined by atomic absorption spectrometry method (AAS), using the equipment iCE 3500 made by Thermo Electron Corporation (USA). The equipment was calibrated with the use of calibration standards from the company ANALYTIKA Ltd. (CZ).

\section{Quality control}

Table 2 presents the limits of detection and the limits of quantification of heavy metals for the spectrometer iCE 3500 [36].

The values of highest concentrations of the models used for calibration $\left(2.0 \mathrm{mg} / \mathrm{dm}^{3}\right.$ for $\mathrm{Cd}, 5.0 \mathrm{mg} / \mathrm{dm}^{3}$ for $\mathrm{Cu}, \mathrm{Zn}, \mathrm{Ni}$ and $\mathrm{Pb}, 7.5 \mathrm{mg} / \mathrm{dm}^{3}$ for $\mathrm{Mn}$ and $10 \mathrm{mg} / \mathrm{dm}^{3}$ for $\mathrm{Fe}$ ) were assumed as the limit of the linear relation of the signal and concentration.

Table 3 shows heavy metals concentrations, determined in the certified reference materials as BCR-482 lichen, prepared by the Institute for Reference Materials and Measurements, Belgium. 
The instrumental detection limits $(I D L)$ and instrumental quantification limits $(I Q L)$ for the spectrometer iCE $3500\left[\mathrm{mg} / \mathrm{dm}^{3}\right]$ [36]

\begin{tabular}{|c|c|c|}
\hline Metal & IDL & IQL \\
\hline $\mathrm{Mn}$ & 0.0016 & 0.020 \\
\hline $\mathrm{Fe}$ & 0.0043 & 0.050 \\
\hline $\mathrm{Ni}$ & 0.0043 & 0.050 \\
\hline $\mathrm{Cu}$ & 0.0045 & 0.033 \\
\hline $\mathrm{Zn}$ & 0.0033 & 0.010 \\
\hline $\mathrm{Cd}$ & 0.0028 & 0.013 \\
\hline $\mathrm{Pb}$ & 0.0130 & 0.070 \\
\hline
\end{tabular}

Comparison of measured and certified concentrations in BCR-482 lichen

\begin{tabular}{|c|c|c|c|c|c|}
\hline \multirow{3}{*}{ Metal } & \multicolumn{2}{|c|}{ BCR-482 lichen } & \multicolumn{2}{|c|}{ AAS } & \multirow{2}{*}{ Dev. ${ }^{* *}$} \\
\hline & Concentration & \pm Measurement uncertainty & Average & $\pm S D^{*}$ & \\
\hline & \multicolumn{4}{|c|}{ [mg/kg d.m.] } & {$[\%]$} \\
\hline $\mathrm{Mn}$ & 33.0 & 0.5 & 31.70 & 0.68 & -3.9 \\
\hline $\mathrm{Fe}$ & 804 & 160 & 771 & 154 & -4.1 \\
\hline $\mathrm{Ni}$ & 2.47 & 0.07 & 2.16 & 0.32 & -13 \\
\hline $\mathrm{Cu}$ & 7.03 & 0.19 & 6.63 & 0.17 & -5.7 \\
\hline $\mathrm{Zn}$ & 100.6 & 2.2 & 95.1 & 2.3 & -5.5 \\
\hline $\mathrm{Cd}$ & 0.56 & 0.02 & 0.53 & 0.03 & -5.3 \\
\hline $\mathrm{Pb}$ & 40.9 & 1.4 & 38.2 & 1.0 & -6.6 \\
\hline
\end{tabular}

* Standard deviation

${ }^{* *}$ Relative difference between the measured $\left(c_{\mathrm{z}}\right)$ and certified $\left(c_{\mathrm{c}}\right)$ concentration $100 \% \cdot\left(c_{\mathrm{z}}-c_{\mathrm{c}}\right) / c_{\mathrm{c}}$

\section{Results and analysis}

The first stage of the research including assessment of heavy metals pollution in the samples of Pleurozium schreberi moss collected in the study area within passive biomonitoring. Table 4 presents the carried out analyses results.

Table 4

Concentrations of heavy metals determined in the mosses collected in the Turawa commune woodlands, Opole province [mg/kg d.m.]

\begin{tabular}{|c|c|c|c|c|c|c|c|}
\hline $\begin{array}{c}\text { Measurement } \\
\text { location No. }\end{array}$ & $\mathbf{M n}$ & $\mathbf{F e}$ & $\mathbf{N i}$ & $\mathbf{C u}$ & $\mathbf{Z n}$ & $\mathbf{C d}$ & $\mathbf{P b}$ \\
\hline 1 & 160 & 388 & $<1.25$ & 7.35 & 57.5 & 1.09 & 38.7 \\
\hline 2 & 241 & 439 & $<1.25$ & 7.42 & 42.2 & 0.96 & 17.6 \\
\hline 3 & 261 & 641 & $<1.25$ & 7.82 & 87.0 & 0.94 & 16.9 \\
\hline 4 & 124 & 528 & $<1.25$ & 9.68 & 64.5 & 0.53 & 9.71 \\
\hline 5 & 1356 & 574 & $<1.25$ & 8.96 & 53.5 & 0.53 & 12.1 \\
\hline 6 & 180 & 614 & $<1.25$ & 6.42 & 43.7 & 0.49 & 13.7 \\
\hline 7 & 568 & 641 & $<1.25$ & 6.71 & 58.7 & 0.52 & 12.4 \\
\hline 8 & 671 & 8148 & 3.67 & 11.4 & 82.6 & 0.50 & 17.8 \\
\hline 9 & 88.1 & 403 & $<1.25$ & 8.29 & 38.5 & $<0.33$ & 9.23 \\
\hline 10 & 130 & 574 & $<1.25$ & 6.96 & 40.7 & 0.49 & 8.68 \\
\hline 11 & 281 & 508 & $<1.25$ & 7.95 & 52.8 & 0.54 & 13.3 \\
\hline Mean & 369 & 1223 & $<1.47$ & 8.08 & 56.5 & $<0.63$ & 15.5 \\
\hline $\boldsymbol{S} \boldsymbol{D}$ & 376 & 2298 & - & 1.45 & 16.3 & - & 8.36 \\
\hline $\boldsymbol{C}[\%]$ & 102 & 189 & - & 18.0 & 28.8 & - & 54.1 \\
\hline
\end{tabular}

- not calculated, $S D$ - Standard deviation, $C V$ - coefficient of variation 
Pollution levels were different in the selected analytes of the mosses collected in designated locations in the study area. Concentrations of $\mathrm{Cd}, \mathrm{Zn}$ and $\mathrm{Pb}$ were determined in the mosses collected in measurement locations 1 and 3 to be higher than the mean value defined for all analysed samples. $\mathrm{Cu}$ concentrations were higher than the mean value in measurement locations 4, 5, 8 and 9. Additionally, higher concentrations of $\mathrm{Zn}, \mathrm{Pb}, \mathrm{Ni}, \mathrm{Mn}$ and $\mathrm{Fe}$ were determined in the samples collected from measurement location 8 . Large $S D$ values in reference to mean $\mathrm{Mn}$ and $\mathrm{Fe}$ concentration values signify different pollution level of mosses, their heterogeneity and indicate the possibility that the studied metals originate from several sources, among others dry deposition from the soil.

The results obtained during active biomonitoring were analysed in the second stage of the research (Table 5).

Table 5

Concentrations of heavy metals determined in the mosses exposed in the Turawa commune woodlands, Opole province [mg/kg d.m.]

\begin{tabular}{|c|c|c|c|c|c|c|c|}
\hline $\begin{array}{c}\text { Measurement } \\
\text { location No. }\end{array}$ & $\mathbf{M n}$ & $\mathbf{F e}$ & $\mathbf{N i}$ & $\mathbf{C u}$ & $\mathbf{Z n}$ & $\mathbf{C d}$ & $\mathbf{P b}$ \\
\hline 1 & 256 & 608 & $<1.25$ & 7.83 & 66.5 & 1.08 & 10.4 \\
\hline 2 & 211 & 488 & $<1.25$ & 7.48 & 53.0 & 0.89 & 16.4 \\
\hline 3 & 318 & 573 & $<1.25$ & 7.00 & 53.1 & 0.88 & 11.3 \\
\hline 4 & 219 & 501 & $<1.25$ & 7,48 & 51.0 & 0.90 & 8.67 \\
\hline 5 & 203 & 635 & $<1.25$ & 7.28 & 56.7 & 0.92 & 11.5 \\
\hline 6 & 241 & 504 & $<1.25$ & 7.98 & 57.7 & 0.94 & 16.1 \\
\hline 7 & 314 & 443 & $<1.25$ & 7.47 & 48.6 & 0.89 & 12.8 \\
\hline 8 & 230 & 883 & $<1.25$ & 7.86 & 66.5 & 1.09 & 27.6 \\
\hline 9 & 278 & 699 & $<1.25$ & 9.01 & 57.1 & 1.00 & 12.4 \\
\hline 10 & 193 & 558 & $<1.25$ & 7.48 & 50.9 & 0.93 & 7.92 \\
\hline 11 & 210 & 515 & $<1.25$ & 7.41 & 52.7 & 0.93 & 13.5 \\
\hline Blind sample & 154 & 308 & $<1.25$ & 7.52 & 42.1 & 0.58 & 11.1 \\
\hline Mean & 236 & 583 & $<1.25$ & 7.65 & 54.7 & 0.92 & 13.3 \\
\hline $\boldsymbol{S} \boldsymbol{C}$ & 44 & 124 & - & 0.50 & 6.93 & 0.13 & 5.16 \\
\hline $\boldsymbol{C}[\boldsymbol{\sigma}]$ & 18.5 & 21.3 & - & 6.86 & 10.7 & 7.89 & 39.8 \\
\hline
\end{tabular}

- not calculated, $S D$ - Standard deviation, $C V$ - coefficient of variation

By analysing the results of active biomonitoring we are able to identify the locations with larger or smaller deposition of a given analyte to air, during the three-month period of moss samples exposition. The highest metals concentrations were determined in the moss samples exposed in measurement locations 1, 6, 8 and 9. The most significant pollution source in these locations was increased communication traffic, which was present during samples exposition in holiday season.

Considerably lower SD values (9 times lower for Mn and 19 times lower for Fe) in reference to the research results of passive method signify larger homogeneity of the mosses exposed in the study area, which results from their preparation methodology [35], showing at the same time restricted influence of the dry deposit from soil on the result of active biomonitoring study.

The maps in Figures 2-7 present spatial distribution of analytes determined in moss samples, both in passive biomonitoring (metal concentrations in [mg/ $\mathrm{kg} \mathrm{d.m.]} \mathrm{determined}$ in mosses collected from the study area) and active (absolute concentrations of analytes $c=c_{\mathrm{z}}-c_{0}$; where: $c_{\mathrm{z}}$ - concentration measured in $[\mathrm{mg} / \mathrm{kg} \mathrm{d} . \mathrm{m}],. c_{0}$ - concentration in blind sample in $[\mathrm{mg} / \mathrm{kg} \mathrm{d.m.]}$ ) in the research area. 
a)

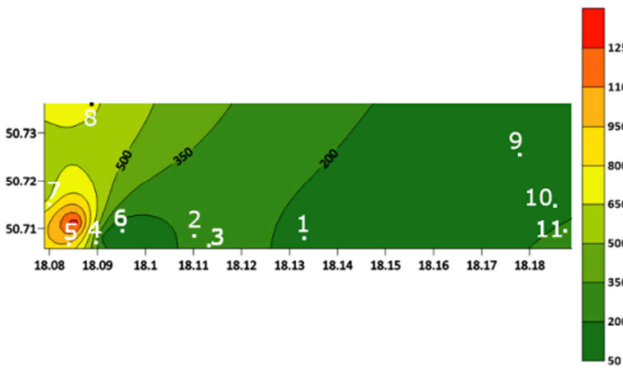

b)

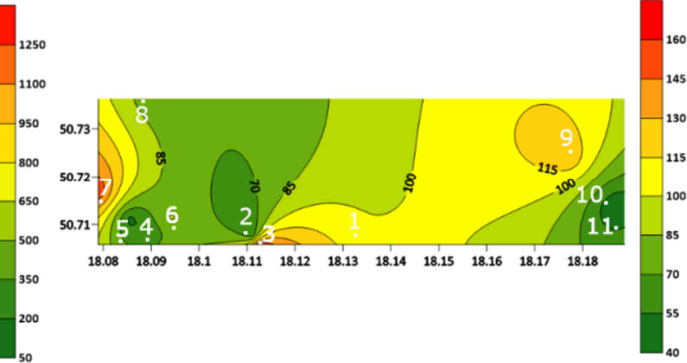

Fig. 2. Spatial distribution of $\mathrm{Mn}$ in the research area determined on the basis of concentration of the analyte in moss samples [mg/kg d.m.]: a) collected by passive method, b) exposed in active biomonitoring

a)

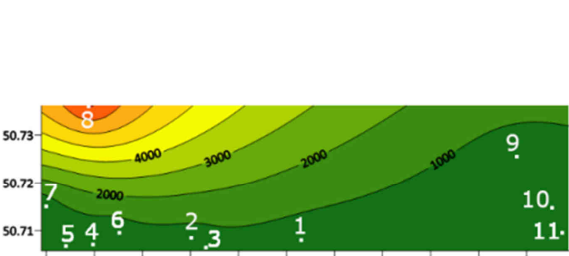

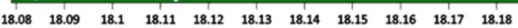

b)

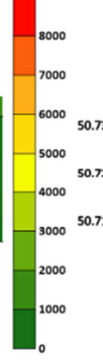

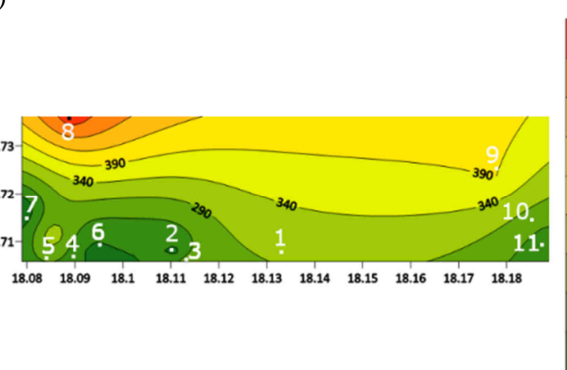

Fig. 3. Spatial distribution of Fe in the research area determined on the basis of concentration of the analyte in moss samples [mg/kg d.m.]: a) collected by passive method, b) exposed in active biomonitoring

a)

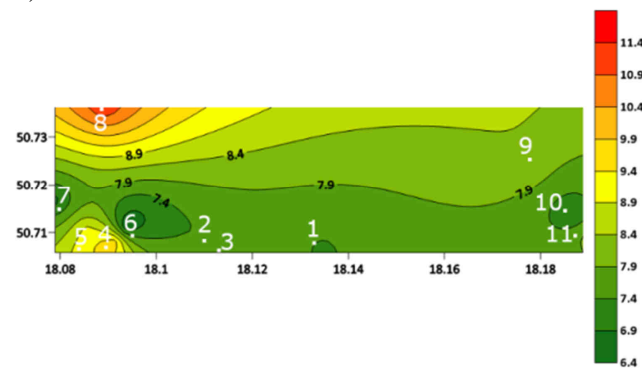

b)

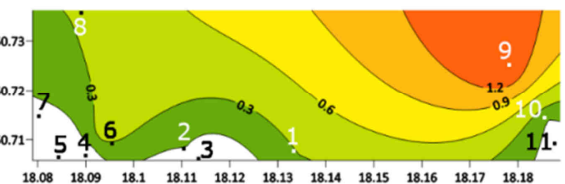

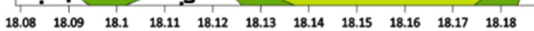

Fig. 4. Spatial distribution of $\mathrm{Cu}$ in the research area determined on the basis of concentration of the analyte in moss samples [mg/kg d.m.]: a) collected by passive method, b) exposed in active biomonitoring 
a)

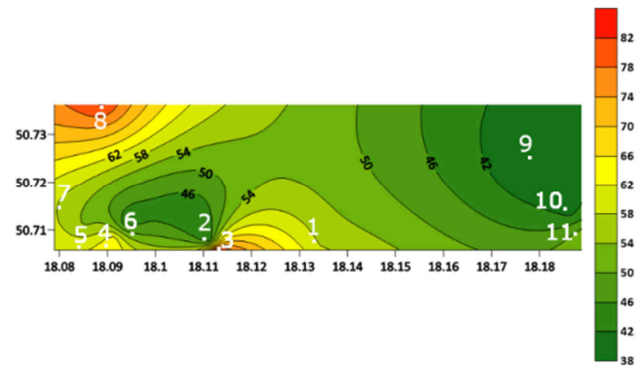

b)

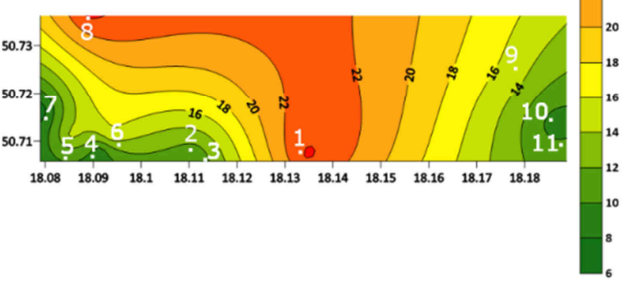

Fig. 5. Spatial distribution of $\mathrm{Zn}$ in the research area determined on the basis of concentration of the analyte in moss samples [mg/kg d.m.]: a) collected by passive method, b) exposed in active biomonitoring

a)

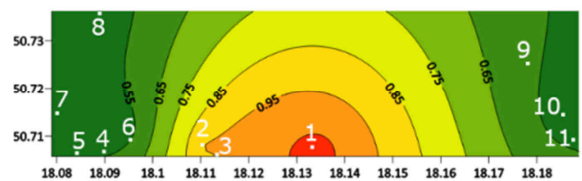

b)

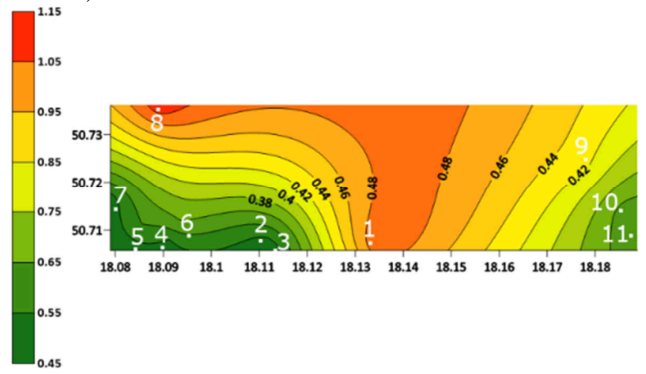

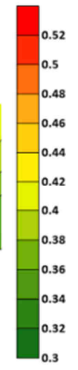

Fig. 6. Spatial distribution of $\mathrm{Cd}$ in the research area determined on the basis of concentration of the analyte in moss samples [mg/kg d.m.]: a) collected by passive method, b) exposed in active biomonitoring

a)

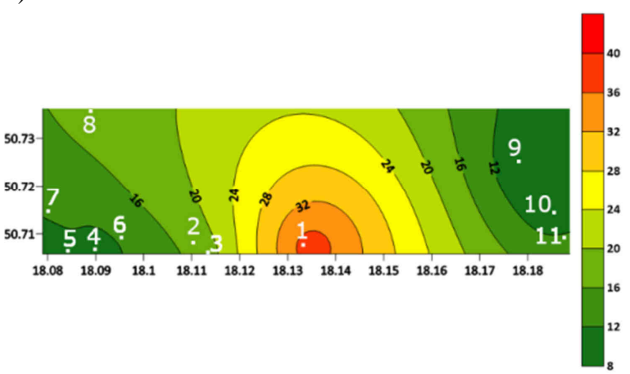

b)

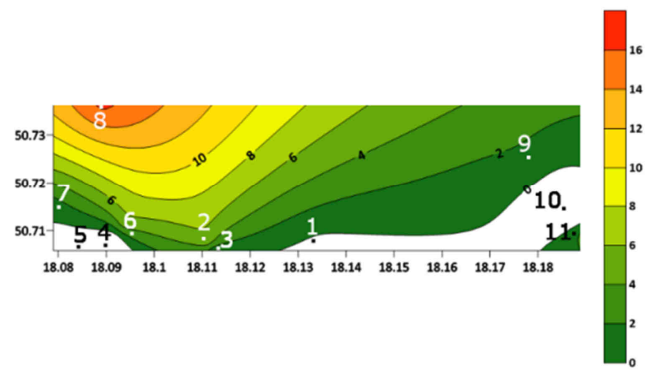

Fig. 7. Spatial distribution of $\mathrm{Pb}$ in the research area determined on the basis of concentration of the analyte in moss samples [mg/kg d.m.]: a) collected by passive method, b) exposed in active biomonitoring

Comparison of spatial distribution of metals in the research area, determined on the basis of the determined concentration of analytes in mosses one can state that passive and active biomonitoring methods cannot be used alternatively but they can be complementary. This results from too many variables which influence the research results obtained by both 
methods, among others mosses lifetime/exposition, climate, influencer of secondary deposition from soil, selection of measurement locations. Simultaneous application of both methods may help detect, for example, concentrated sources of pollution or emission from distant sources occurring during mosses exposition period. Analysis of the carried out research results proved that in mosses collected by passive method in location 9, cadmium concentration was below detection limit of the applied analytical method. However, the active method detected in this location concentrations above the mean value set for all measurement locations. The pollution level of atmospheric aerosol with $\mathrm{Cd}$ in this measurement location can be influenced by emission from distant sources, e.g. burning of communal waste during the three-month exposition period of mosses [37].

In order to determine uncertainty of the measurement method, moss samples were analysed three times, maintaining the whole cycle of the research method. For the moss samples collected/exposed in measurement locations, the value of coefficient of variation $C V$ determined on the basis of standard deviation value $S D\left(C V[\%]=\left(S D_{i} / c_{x, \text { aver }, i}\right) \cdot 100\right.$ $\%$, where: $S D_{i} / c_{x, \text { aver }, i}$ is the standard deviation calculated for the $i$-series $(i=11)$, referring to the mean value from that series $\left.\left(c_{x, a v e r, i}\right)\right)$ is within the range 18-189\% for the passive method and 6.86-39.8 \% for the active method. The active method, considering the proper moss samples exposition preparation method, exposition at the height of approximately $1.5 \mathrm{~m}$ (which limits the influence of secondary deposition from soil) seems to be more reliable and illustrate the actual heavy metals pollution levels in atmospheric aerosol during the three-month exposition period of mosses.

\section{Conclusion}

Mosses are perceived as one of the major bioindicators of heavy metal pollution in air biomonitoring. Analysis of, among others, heavy metals concentrations captured in mosses provides much information regarding the pollution introduced to atmospheric aerosol, allows to asses changes in air quality and to identify the sources of pollution.

Currently, two methods of atmospheric aerosol biomonitoring with the use of mosses are used: passive and active. The research results obtained thanks to the use of these methods have not been compared so far. This is the result of heterogeneity of the research material and many factors, which influence the final result.

On the basis of carried out research, the authors suggest that passive and active biomonitoring methods should not be used alternatively in the same study area, but they can be complementary. Simultaneously it was proved that active biomonitoring method produces more reliable results (lower $C V$ values) in comparison to passive biomonitoring.

\section{References}

[1] Markert B, Wappelhorst O, Weckert V, Herpin U, Siewers U, Friese K, et al. The use of bioindicators for monitoring the heavy-metal status of the environment. J Radioanal Nucl Chem. 1999;240:425-9. DOI: 10.1007/BF02349387.

[2] Vingiani S, De Nicola F, Purvis WO, Concha-Graña E, Muniategui-Lorenzo S, López-Mahía P, et al. Active biomonitoring of heavy metals and PAHs with mosses and lichens: A case study in the cities of Naples and London. Water Air Soil Pollut. 2015;226(8):240. DOI: 10.1007/s11270-015-2504-5.

[3] Ciesielczuk T, Olszowski T, Prokop M, Kłos A. Application of mosses to identification of emission sources of polycyclic aromatic hydrocarbons. Ecol Chem Eng S. 2012;19(4):585-95. DOI: 10.2478/v10216-011-0041-8. 
[4] Shvetsova MS, Kamanina IZ, Frontasyeva MV, Madadzada AI, Zinicovscaia II, Pavlov SS, et al. Active moss biomonitoring using the "Moss Bag Technique" in the park of Moscow. Phys Part Nuclei Lett. 2019;16:994-1003. DOI: 10.1134/S1547477119060293.

[5] Kosior G, Samecka-Cymerman A, Brudzińska-Kosior A. Transplanted moss hylocomium splendens as a bioaccumulator of trace elements from different categories of sampling sites in the Upper Silesia Area (SW Poland): Bulk and dry deposition impact. Bull Environ Contam Toxicol. 2018;101:479-85. DOI: 10.1007/s00128-018-2429-y.

[6] Zawadzki K, Samecka-Cymerman A, Kolon K, Wojtuń B, Mróz L, Kempers AJ. Metals in Pleurozium schreberi and Polytrichum commune from areas with various levels of pollution. Environ Sci Pollut Res. 2016;23:11100-8. DOI: 10.1007/s11356-016-6278-0.

[7] Rajfur M. Algae - heavy metals biosorbent. Ecol Chem Eng S. 2013;20(1):23-40. DOI: 10.2478/eces-2013-0002.

[8] Świsłowski P, Rajfur M, Wacławek M. Influence of heavy metal concentration on chlorophyll content in Pleurozium schreberi mosses. Ecol Chem Eng S. 2020;27(4):591-601. DOI: 10.2478/eces-2020-0037.

[9] Macedo-Miranda G, Avila-Pérez P, Gil-Vargas P, Zarazua G, Sanchez-Meza JC, Zepeda-Gomez C, et al. Accumulation of heavy metals in mosses: a biomonitoring study. SpringerPlus. 2016;5:715. DOI: 10.1186/s40064-016-2524-7.

[10] Kawser AM, Baki MA, Kundu GK, Islam MdS, Islam MdM, Hossain MdM. Human health risks from heavy metals in fish of Buriganga river, Bangladesh. SpringerPlus. 2016;5:1697. DOI: 10.1186/s40064-016-3357-0.

[11] Noh K, Thi LT, Jeong BR. Particulate matter in the cultivation area may contaminate leafy vegetables with heavy metals above safe levels in Korea. Environ Sci Pollut Res. 2019;26:25762-74. DOI: $10.1007 / \mathrm{s} 11356-019-05825-4$.

[12] Vetrimurugan E, Brindha K, Elango L, Ndwandwe OM. Human exposure risk to heavy metals through groundwater used for drinking in an intensively irrigated river delta. Appl Water Sci. 2017;7:3267-80. DOI: 10.1007/s13201-016-0472-6.

[13] Grodzińska K, Frontasyeva M, Szarek-Łukaszewska G, Klich M, Kucharska-Fabiś A, Gundorina SF, et al. Trace element contamination in industrial regions of poland studied by moss monitoring. Environ Monit Assess. 2003;87:255-70. DOI: 10.1023/A:1024871310926.

[14] Szczepaniak K, Astel A, Bode P, Sarbu C, Biziuk M, Raińska E, et al. Assessment of atmospheric inorganic pollution in the urban region of Gdańsk, Northern Poland. J Radioanal Nucl Chem. 2006;270:35-42. DOI: 10.1007/s10967-006-0418-9.

[15] Boryło A, Romańczyk G, Skwarzec B. Lichens and mosses as polonium and uranium biomonitors on Sobieszewo Island. J Radioanal Nucl Chem. 2017;311:859-69. DOI: 10.1007/s10967-016-5079-8.

[16] Kapusta P, Stanek M, Szarek-Łukaszewska G, Godzik B. Long-term moss monitoring of atmospheric deposition near a large steelworks reveals the growing importance of local non-industrial sources of pollution. Chemosphere. 2019;230:29-39. DOI: 10.1016/j.chemosphere.2019.05.058.

[17] Qarri F, Lazo P, Allajbeu S, Bekteshi L, Kane S, Stafilov T. The evaluation of air quality in Albania by moss biomonitoring and metals atmospheric deposition. Arch Environ Contam Toxicol. 2019;76:554-71. DOI: 10.1007/s00244-019-00608-x.

[18] Lazo P, Stafilov T, Qarri F, Allajbeu S, Bekteshi L, Frontasyeva M, et al. Spatial distribution and temporal trend of airborne trace metal deposition in Albania studied by moss biomonitoring. Ecol Indicat. 2019;101:1007-17. DOI: 10.1016/j.ecolind.2018.11.053.

[19] Maxhuni A, Lazo P, Kane S, Quarri F, Marku E, Harmens H. First survey of atmospheric heavy metal deposition in Kosovo using moss biomonitoring. Environ Sci Pollut Res. 2016;23:744-55. DOI: 10.1007/s11356-015-5257-1.

[20] Chaligava O, Shetekauri S, Badawy WM, Frontasyeva MV, Zinicovscaia I, Shetekauri T, et al. Characterization of trace elements in atmospheric deposition studied by moss biomonitoring in Georgia. Arch Environ Contam Toxicol. 2021;80:350-67. DOI: 10.1007/s00244-020-00788-x.

[21] Gallego-Cartagena E, Morillas H, Carrero JA, Madariaga JM, Maguregui M. Naturally growing grimmiaceae family mosses as passive biomonitory of heavy metals pollution in urban-industrial atmospheres from the Bilbao Metropolitan area. Chemosphere. 2021;263:128190. DOI: 10.1016/j.chemosphere.2020.128190.

[22] Cowden P, Aherne J. Assessment of atmospheric metal deposition by moss biomonitoring in aregion under the influence of a long standing active aluminium smelter. Atmosph Environ. 2019;201:84-91. DOI: 10.1016/j.atmosenv.2018.12.022.

[23] Špirić Z, Vučković I, Stafilov T, Kusan V, Beceva K. Biomonitoring of air pollution with mercury in Croatia by using moss species and CV-AAS. Environ Monit Assess. 2014;186:4357-66. DOI: 10.1007/s10661-014-3704-y. 
[24] Castello MA. Comparison between two moss species used as transplants for airborne trace element biomonitoring in NE Italy. Environ Monit Assess. 2007;133:267-76. DOI: 10.1007/s10661-006-9579-9.

[25] Aničić Urošević M, Vuković G, Jovanović P, Vujičić M, Sabovljević A, Sabovljević M, et al. Urban background of air pollution: evaluation through moss bag biomonitoring of trace elements in Botanical garden. Urban Forestry Urban Greening. 2017;25:1-10. DOI: 10.1016/j.ufug.2017.04.016.

[26] Coskun M, Steinnes E, Coskun M, Cayir A. Comparison of epigeic moss (Hypnum cupressiforme) and lichen (Cladonia rangiformis) as biomonitor species of atmospheric metal deposition. Bull Environ Contam Toxicol. 2009;82:1-5. DOI: 10.1007/s00128-008-9491-9.

[27] Kolon K, Samecka-Cymerman A, Kempers AJ., Mróz L. Pleurozium schreberi of the Tatra mountains (Poland) used as a bioindicational system for observing long range atmospheric transport of chemical elements. J Atmos Chem. 2010;66:157-66. DOI: 10.1007/s10874-011-9198-x.

[28] Dołęgowska S, Migaszewski ZM. Biomonitoring with mosses: Uncertainties related to sampling period, intrasite variability, and cleaning treatments. Ecol Indicat. 2019;101:296-302. DOI: 10.1016/j.ecolind.2019.01.033.

[29] Szarek-Łukaszewska G, Grodzińska K, Braniewski S. Heavy metal concentration in the moss Pleurozium schreberi in the Niepołomice Forest, Poland: Changes during 20 years. Environ Monit Assess. 2002;79:231-7. DOI: 10.1023/A:1020226526451.

[30] Zechmeister HG, Riss A, Hanus-Illnar A. Biomonitoring of atmospheric heavy metal deposition by mosses in the vicinity of industrial sites. J Atmos Chem. 2004;49:461-77. DOI: 10.1007/s10874-004-1260-5.

[31] Samecka-Cymerman A, Kosior G, Kolon K, Wojtuń B, Zawadzki K, Rudecki A, et al. Pleurozium schreberi as bioindicator of mercury pollution in heavily industrialized region. $\mathrm{J}$ Atmos Chem. 2013;70:105-14. DOI: 10.1007/s10874-013-9256-7.

[32] ICP Vegetation, 2015. Heavy metals, nitrogen and pops in European mosses: 2015 survey. Available from: https://icpvegetation.ceh.ac.uk/sites/default/files/MossmonitoringMANUAL-2015-17.07.14.pdf.

[33] Jiang Y, Fan M, Hu R, Zhao J, Wu Y. Mosses are better than leaves of vascular plants in monitoring atmospheric heavy metal pollution in urban areas. Inter J Environ Res Public Health. 2018;15:1105. DOI: 10.3390/ijerph15061105.

[34] Shetekauri S, Chaligava O, Shetekauri T, Kvlividze A, Kalabegishvili T, Kirkesali E, et al. Biomonitoring air pollution using moss in Georgia. Polish J Environ Stud. 2018;27(5):2259-66. DOI: 10.15244/pjoes/73798.

[35] Świsłowski P, Kosior G, Rajfur M. The influence of preparation methodology on the concentration of heavy metals in Pleurozium schreberi moss samples prior to use in active biomonitoring studies. Environ Sci Pollut Res. 2021;28(8):10068-76. DOI: 10.1007/s11356-020-11484-7.

[36] iCE 3000 Series AA Spectrometers Operators Manuals. Cambridge: Thermo Fisher Scientific, 2011. Available from: http://photos.labwrench.com/equipmentManuals/9291-6306.pdf.

[37] Gerdol R, Marchesini R, Iacumin P, Brancaleoni L. Monitoring temporal trends of air pollution in an urban area using mosses and lichens as biomonitors. Chemosphere. 2014;108:388-95. DOI: 10.1016/j.chemosphere.2014.02.035. 